\section{Evaluation of biogenic amines levels, and biochemical and microbiological characterization of Italian-type salami sold in Rio de Janeiro, Brazil}

\author{
Luiz Felipe Lopes dos Santos,' \\ Eliane Teixeira Mársico, ${ }^{1}$ César Aquiles \\ Lázaro, ${ }^{1,2}$ Rose Teixeira, ${ }^{1}$ Laís Doro, ${ }^{1}$ \\ Carlos Adam Conte Júnior ${ }^{1}$
}

'Department of Food Technology, Faculty of Veterinary Medicine, Fluminense

Federal University, Niterói, RJ, Brazil;

${ }^{2}$ Laboratory of Pharmacology and

Toxicology, Faculty of Veterinary

Medicine, National University of San

Marcos, Lima, Peru

\section{Abstract}

The objective of the present study was to evaluate the levels of biogenic amines (cadaverine, putrescine, tyramine, histamine, spermidine and spermine) by high performance liquid chromatography (HPLC) and the physicochemical (moisture, lipids, proteins, $\mathrm{pH}$, water activity and fixed mineral residue) and microbiological (lactic acid bacteria and aerobic heterotrophic mesophilic bacteria count) characteristics of six Italian-type salami brands sold in the city of Niteroi (Rio de Janeiro, Brazil). The salami showed lactic acid bacteria count from 5.7 to 8.6 $\mathrm{CFU} \bullet \mathrm{mL}^{-1}$, and heterotrophic mesophilic bacteria count from 5.8 to $8.7 \mathrm{CFU} \bullet \mathrm{mL}^{-1}$. Three brands showed moisture contents above $35 \%$ and one brand had protein content below $25 \%$. The mean values obtained for the amines were: 197.43, $143.29,73.02,4.52,90.66$ and $36.17 \mathrm{mg}^{\bullet} \mathrm{kg}^{-1}$ for tyramine, putrescine, cadaverine, spermidine, histamine, and spermine respectively. Two brands presented histamine contents above the legal limit established in $100 \mathrm{mg}^{\bullet} \mathrm{kg}^{-1}$. We concluded that the evaluated salami presented a wide variation in the count of the bacterial groups with a predominance of lactic acid bacteria. The moisture contents indicate insufficient drying before commercialization and protein content had values below the minimum limit determined by the Brazilian legislation. Finally, the levels of biogenic amines found could cause adverse reactions in susceptible consumers, depending of the amount and frequency of intake of these products.

\section{Introduction}

In Brazil, the manufacture of salami began when Italian immigrants arrived at the South of the country where the climate favors its production (Terra et al., 2004). However, salami is currently produced throughout the country, and represents a high percentage of the sausages consumed by the Brazilian population. According to the Brazilian association of pork meat product manufacturers in 2009 salami represented $2 \%$ of the entire household pork meat consumption, and the production was about 142 tons per day (Peltier, 2013).

The typical flavor and aroma of salami is produced by several chemical reactions involving proteins, hydrocarbons and lipids during maturation (Scheid, 2001). In addition, factors such as the type of raw material, process conditions, type of starter culture, types of flavorings and spices, promote the production of volatile organic compounds (alcohol, ketones, aldehydes and furans) and non-volatile compounds (amino acids, peptides, sugars and nucleotides) responsible for the final sensory quality of the product (Ordóñez et al., 1999).

Salami is classified as a cured, fermented, matured and dried meat product, consumed without thermal treatment (Brazilian Republic, 2000). Thus, the production stages must ensure the safety of the product. To ensure the safety in sausage manufacture, normally lactic acid bacteria strains that produce antimicrobial metabolites such as organic acids and bacteriocins, are used aiming at preventing the growth of food-spoilage and/or pathogenic microorganisms (Ross et al., 2002). However, this bacterial group can also produce biogenic amines (BA) by the action of the decarboxylase enzyme on specific free amino acids (Suzzi and Gardini, 2003).

The presence of BA in food is important for toxicological reasons. Tyramine promotes hypertensive crisis and migraine in susceptible persons; high doses of alimentary histamine and malfunction or reduced activity of diamine oxidase (DA0) can result in high histamine blood levels, which consequently overload the internal hepatic inactivation system of histamine N-methyltransferase (HMT) and may cause headache, itching, nausea, vomiting and diarrhea (EFSA, 2011); putrescine and cadaverine can generate carcinogenic substances (nitrosamines) in the presence of nitrites. On the other hand, cadaverine, putrescine, tyramine and histamine can be considered as potential indicators of food spoilage in bovine, fish, chicken and pork meat (Halász et al., 1994; Vinci and Antonelli, 2002; Rodriguez et al., 2014).

Tyramine and cadaverine are more frequently found in salami, besides tryptamine, putrescine and histamine, but fluctuations of BA content in the same type of salami have been reported (Suzzi and Gardini, 2003). Currently, consumers increasingly demand quality foods with particular sensory characteristics. In
Correspondence: Carlos Adam Conte Júnior, Department of Food Technology, Faculty of Veterinary Medicine, Fluminense Federal University, Rua Vital Brazil Filho 64, Santa RosaNiterói, 24230-340 Rio de Janeiro, Brazil. Tel: +55.021.2629.9545 - Fax: +55.021.2629.9541

E-mail: carlosconte@id.uff.br

Key words: Biogenic amines; Food safety; Proximate composition; Food quality; Salami.

Contributions: LFLdS, CACJ and ETM designed the study and developed the statistical analyses; LFLdS and CAL developed the HPLC analysis; LFLdS, RT and LD performed the bacteriological test proximate composition.

Conflict of interest: the authors declare no potential conflict of interest.

Acknowledgments: the authors are thankful for the financial support of the State of Rio de Janeiro Carlos Chagas Filho Research Foundation (FAPERJ), process numbers E26/103.003/2012 and E-26/111.673/2013; and the National Council for Scientific and Technological Development (CNPq), process numbers 311361/2013-7 and 401922/2013-8. The authors thank Sântila Bravo and Gabriela Barbosa for their technical support in the present study.

Received for publication: 10 May 2014.

Revision received: 8 April 2015.

Accepted for publication: 13 April 2015.

This work is licensed under a Creative Commons Attribution 3.0 License (by-nc 3.0).

(C) Copyright L.F. Lopes dos Santos et al., 2015 Licensee PAGEPress, Italy

Italian Journal of Food Safety 2015; 4:4048 doi:10.4081/ijfs.2015.4048

Brazil there is a technical regulation for the identity and quality of Italian-type salami, which defines sensory and physicochemical requirements (Brazilian Republic, 2000). However, the BA levels are not considered. The objective of the present study was to assess the levels of BA and the physicochemical and microbiological characteristics of Italian-type salami sold in the city of Niteroi (Rio de Janeiro, Brazil).

\section{Materials and Methods}

\section{Sample collection}

The samples were randomly collected from six commercial brands named A, B, C, D, E and $\mathrm{F}$ of Italian-type salami, in markets located in the city of Niterói, and were transported to the School of Veterinary of the Fluminense Federal University (Niterói, RJ) where, after the package integrity verification, the samples were stored under refrigeration $\left(4^{\circ} \mathrm{C}\right)$ until the bacteriological and physicochemical analyses. These were whole and wrapped in vacuum pac- 
kaging, weighing between 350 and 750 g, with diameter range from 50 to $66 \mathrm{~mm}$. According to the Brazilian law the period of fermentation or maturation depends on the type of technological process used, usually ranging of 25 to 50 days (Brazilian Republic, 2000; Caccioppoli et al., 2006).

\section{Bacteriological analyses}

Samples (10 g) were aseptically removed from the interior of each salami and homogenized with $90 \mathrm{~mL}$ peptone water in a Stomacher (Seward ${ }^{\circledR} 80$, Worthing, UK). Then, decimal serial dilutions were prepared from this mixture. For aerobic heterotrophic mesophilic bacteria count (AHMBC) each sample was plated in duplicate on standard culture agar (Oxoid, Cambridge, UK). Lactic acid bacteria (LAB) determination was carried out seeding each sample in duplicate on double layer plates containing Man, Rogosa and Sharpe culture medium (MRS) (Himedia, Mumbai, India). Plates were incubated at $35^{\circ} \mathrm{C}$ for $48 \mathrm{~h}$ and the colonies were counted subsequently. The results were expressed in $\mathrm{CFU} \bullet \mathrm{mL}^{-1}$ (Brazilian Republic, 2003).

\section{Proximate composition}

The salami samples were ground and homogenized in an Oster blender (Oster, New York, USA). Moisture, fixed mineral residue, proteins and lipids were estimated in duplicate according to methodologies described by the Adolf Lutz Institute (Zenebon et al., 2008); pH and water activity were determined in triplicate. The reagents used were analytical grade.

For moisture determination, $5 \mathrm{~g}$ samples were ground and placed in an oven at $105^{\circ} \mathrm{C}$. Moisture content was calculated as the difference between the initial weight and the final weight of the sample (after reaching a constant weight). After moisture determination, the dried sample was used to obtain the lipid content by direct extraction by Soxhlet method (gravimetric). Fixed mineral residue was determined by the ignition of a $2 \mathrm{~g}$ sample in a muffle furnace at $550^{\circ} \mathrm{C}$ until white or light gray ashes were obtained. Protein was determined from the nitrogen content obtained by the Kjeldahl method. pH and water activity were assessed by electrometric processes using a DM-22 pH meter (Digimed, São Paulo, Brazil) and a Pawkit meter (Decagon Devices ${ }^{\circledR}$, Washington, DC, USA) respectively, directly in the sample and following the manufacturers' instructions.

\section{Biogenic amine analysis}

Cadaverine, putrescine, tyramine, spermidine, spermine and histamine were quantified using the methodology suggested by Lazaro et al. (2013). The extraction was carried out in a $5 \mathrm{~g}$ sample added of 5\% 1:1 (v:w) perchloric acid solution. The mixture was kept under refrigeration $\left(4^{\circ} \mathrm{C}\right)$, periodically stirred, for one hour, and subsequently centrifuged by $503 g$ at $4^{\circ} \mathrm{C}$ for $10 \mathrm{~min}$. The supernatant was submitted to an initial filtration (Whatman ${ }^{\circledR}$ $\mathrm{n}^{0} .1$ ) followed by the addition of $2 \mathrm{~N}$ sodium hydroxide to $\mathrm{pH}>6$. Then, the sample was placed in an ice bath for 20 minutes and a second filtration was carried out under the same conditions. Next, $2 \mathrm{~N}$ sodium hydroxide was added until $\mathrm{pH}>12$ was reached and, immediately derivatization was conducted through the addition of $40 \mathrm{~mL}$ benzoyl chloride. The mixture was homogenized and allowed to stand for 20 minutes at room temperature. $1 \mathrm{~mL}$ diethyl ether was added twice, reserving the ether phase (supernatant). The ether was evaporated under flowing nitrogen and the remnant was re-suspended in $500 \mathrm{~mL}$ of mobile phase. The chromatographic system used was Prominence UFLC (Shimadzu, Kyoto, Japan) equipped with a DGU-20A5 degassing unit, SIL-20AC auto injector, LC-20AD quaternary pump, CTO-20A column oven, SPD-M20A diode array detector and CBM-20 $0^{a}$ communication system. The mobile phase was a mixture of acetonitrile (Tedia ${ }^{\circledR}$, Fairfield, OH, USA) and ultrapure water (Millipore, Molsheim, France) 42:58 (v/v) previously degassed in ultrasonic bath (Cleaner USC 2800 A, São Paulo, Brazil). A TR-016057 N26243 Tracer Extrasil ODS2 (15 x $0.46 \mathrm{~cm}$, id. $5 \mathrm{~m}$ ) column (Teknokroma, Barcelona, Spain) and an Ascentis C18 (2 x $0.40 \mathrm{~cm}$, id. $5 \mathrm{~m}$ ) guard column (Supelco, Bellefonte, PA, USA) were used for amine separation.

The chromatographic conditions were: 1 mL.min ${ }^{-1}$ flow, with isocratic mobile phase, 20 $\mathrm{mL}$ injection volume, $198 \mathrm{~nm}$ UV detector wavelength, $20^{\circ} \mathrm{C}$ oven temperature and 15 minutes run time. Each sample was injected four times interspersed by 10 min washings with acetonitrile (100\%). Amines were quantified against external standards using standard stock solutions of each standard amine in $0.1 \mathrm{~N}$ $\mathrm{HCl}$ derivatized and analyzed similarly than the samples. The reagents and standards used were HPLC grade.

\section{Statistical analyses}

The results obtained were submitted to variance analyses and the means were compared by the Bonferroni test at $5 \%$ significance level. All the analyses were performed using the GraphPad Prism version 5.00 statistical package for Windows commercially available (GraphPad Software, San Diego, CA, USA).

\section{Results and Discussion}

\section{Bacterial count}

The bacterial count varied according to the brand, with $B$ and $E$ presenting the highest and lowest AHMBC and LAB values, respectively (Figure 1). The bacterial count variations may be attributed to different manufacturing processes used by the different brands. Our results are slightly lower than those reported by Ambrosiadis et al. (2004) who reported mean value of $8 \log \mathrm{CFU} \bullet \mathrm{mL}^{-1}$ for $\mathrm{AHMBC}$ and $\mathrm{LAB}$ in traditional Greek fermented sausage, an artisanal product. As expected, LAB was the predominant bacterial group. LAB presence in this type of products is desirable because it may have limited the development of pathogenic and spoilage bacteria, due to the production of high levels of lactic acid. Under this condition, meat soluble proteins coagulate, water retention capacity is reduced and other metabolites that provide the particular characteristics in fermented sausages are produced (Lücke, 2000). However, LAB are also the major producers of BA in fermented products (Cardozo et al., 2013). Parente et al. (2001)

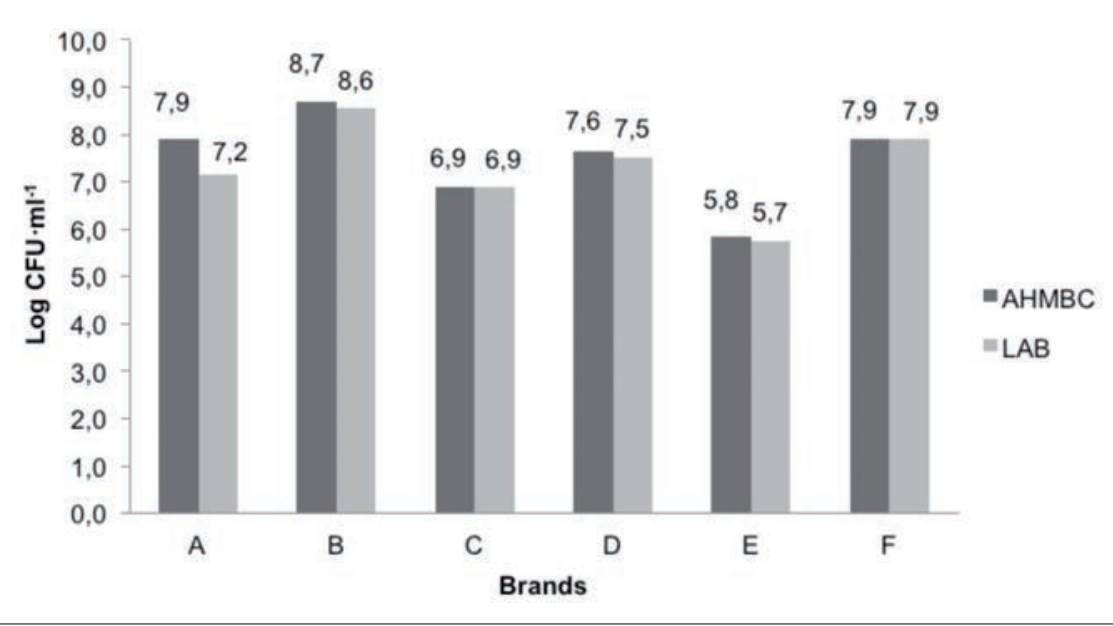

Figure 1. Aerobic heterotrophic mesophylic bacterial count (AHMBC) and lactic acid bacteria count (LAB) in different Italian-type salami brands commercialized in Niteroi, RJ, Brazil. 
observed a high correlation between LAB and levels of putrescine, cadaverine, histamine, tyramine, spermidine and spermine during Italian sausage maturation.

Although LAB is the predominant bacterial group in salami, spoilage and pathogenic bacteria may be present due to contamination during handling and processing. Although these groups were not assessed in the present study, they can contribute to BA content in salami (Halász et al., 1994; Silva et al., 2013).

\section{Proximate composition}

The results of moisture, lipid, protein, ash and $\mathrm{pH}$ analyses are listed in Table 1. The Italian-type salami of A, E and F brands were within the physicochemical limits established by the Brazilian legislation: up to $0.90,35 \%$, and $32 \%$ for water activity, moisture and lipid, respectively, and at least $25 \%$ for protein (Brazilian Republic, 2000).

The moisture contents of brands B, C and D were above the legal limit of $35 \%$, indicating insufficient drying. This result was also found by Tussi et al. (2008) and Caccioppoli et al. (2006) who observed that moisture content was one of the parameters showing the most frequent noncompliance with legal limits in industrial salami from different regions of Brazil.

The protein content observed in the present study was in accordance with the results found by Caccioppoli et al. (2006), who reported a similar range of values (22.61-27.86\%) in Italian-type salami. Brand D was the only with low protein content. The lipid contents of all the brands were within the legal limit of $32 \%$, and the same result was found by Caccioppoli et al. (2006) and Tussi et al. (2008). The Brazilian law defines that the maturation and drying time depends on the respective technological process (Brazilian Republic, 2000). None of the brands evaluated indicated the period of fermentation or maturation, which range from 25 to 50 days according to the Brazilian law. Our results showed $\mathrm{pH}$ values between 4.99 and 6.87 in the analyzed brands. These variations are attributed to factors that affect the rate of fermentation processing such as time, temperature, relative humidity, specific formulation as the amount of carbohydrates available, the type of sugar used, and the use of condiments that stimulate the formation of lactic acid which may differ among brands (Lima, 2009). A slight increase of pH may be related to a reduction of electrolyte dissociation, an increase of protein buffer concentration and formation of ammonia due to degradation of lactic acid by fungi (Demeyer et al., 1979; Castro et al., 2000).

\section{Biogenic amines}

The results obtained for BAs are shown in Table 2. Tyramine was the predominant amine followed by putrescine, with means of 197.43 $\mathrm{mg} \bullet \mathrm{kg}^{-1}$ and $143.29 \mathrm{mg} \bullet \mathrm{kg}^{-1}$ respectively. Spermine and spermidine had means of 36.17 $\mathrm{mg} \bullet \mathrm{kg}^{-1}$ and $4.52 \mathrm{mg} \bullet \mathrm{kg}^{-1}$ respectively. These two amines are normally present in meat and

Table 1. Results of the physico-chemical analyses (mean \pm standard deviation) of different brands of Italian-type salami brands sold in the market of Niteroi, RJ, Brazil.

\begin{tabular}{|c|c|c|c|c|c|c|}
\hline Brands & Moisture (\%) & Lipids (\%) & Protein (\%) & Ash (\%) & $\mathrm{pH}$ & $\mathrm{a}_{\mathrm{W}}$ \\
\hline A & $\begin{array}{c}30.46 \\
\left( \pm 1.5 g^{b f}\right)\end{array}$ & $\begin{array}{c}28.24 \\
\left( \pm 4.93^{\mathrm{a}}\right)\end{array}$ & $\begin{array}{c}25.33 \\
\left( \pm 0.13^{\mathrm{a}}\right)\end{array}$ & $\begin{array}{c}7.78 \\
\left( \pm 0.39^{\mathrm{a}}\right)\end{array}$ & $\begin{array}{c}6.46 \\
\left( \pm 0.26^{\mathrm{a}}\right)\end{array}$ & $\begin{array}{c}0.81 \\
\left( \pm 0.00^{\mathrm{a}}\right)\end{array}$ \\
\hline B & $\begin{array}{c}40.11 \\
\left( \pm 1.19^{\mathrm{a}}\right)\end{array}$ & $\begin{array}{c}24.47 \\
( \pm 2.19 \mathrm{a})\end{array}$ & $\begin{array}{c}26.14 \\
\left( \pm 0.00^{\mathrm{a}}\right)\end{array}$ & $\begin{array}{c}5.27 \\
( \pm 0.99 \mathrm{a})\end{array}$ & $\begin{array}{c}5.27 \\
\left( \pm 0.01^{\mathrm{b}}\right)\end{array}$ & $\begin{array}{c}0.88 \\
\left( \pm 0.00^{\mathrm{a}}\right)\end{array}$ \\
\hline $\mathrm{C}$ & $\begin{array}{c}41.15 \\
\left( \pm 0.82^{\mathrm{a}}\right)\end{array}$ & $\begin{array}{c}16.18 \\
\left( \pm 0.09^{\mathrm{a}}\right)\end{array}$ & $\begin{array}{c}34.88 \\
\left( \pm 1.91^{\mathrm{b}}\right)\end{array}$ & $\begin{array}{c}7.27 \\
\left( \pm 0.81^{\mathrm{a}}\right)\end{array}$ & $\begin{array}{c}6.87 \\
\left( \pm 0.01^{\mathrm{c}}\right)\end{array}$ & $\begin{array}{c}0.86 \\
\left( \pm 0.00^{\mathrm{bc}}\right)\end{array}$ \\
\hline D & $\begin{array}{c}37.05 \\
\left( \pm 1.55^{\mathrm{ba}}\right)\end{array}$ & $\begin{array}{c}27.05 \\
\left( \pm 2.57^{\mathrm{a}}\right)\end{array}$ & $\begin{array}{c}23.79 \\
\left( \pm 0.51^{\mathrm{a}}\right)\end{array}$ & $\begin{array}{c}4.36 \\
\left( \pm 1.52^{\mathrm{a}}\right)\end{array}$ & $\begin{array}{c}4.99 \\
\left( \pm 0.00^{\mathrm{db}}\right)\end{array}$ & $\begin{array}{c}0.85 \\
\left( \pm 0.00 a^{b}\right)\end{array}$ \\
\hline $\mathrm{E}$ & $\begin{array}{c}31.82 \\
\left( \pm 1.59^{b}\right)\end{array}$ & $\begin{array}{c}24.50 \\
\left( \pm 0.39^{\mathrm{a}}\right)\end{array}$ & $\begin{array}{c}32.35 \\
( \pm 0.38 \mathrm{bc})\end{array}$ & $\begin{array}{c}6.71 \\
\left( \pm 0.01^{\mathrm{a}}\right)\end{array}$ & $\begin{array}{c}5.55 \\
\left( \pm 0.03^{\mathrm{eb}}\right)\end{array}$ & $\begin{array}{c}0.86 \\
\left( \pm 0.01^{\mathrm{a}}\right)\end{array}$ \\
\hline $\mathrm{F}$ & $\begin{array}{c}33.56 \\
\left( \pm 2.63^{\text {ba }}\right)\end{array}$ & $\begin{array}{c}25.54 \\
\left( \pm 2.59^{\mathrm{a}}\right)\end{array}$ & $\begin{array}{c}27.40 \\
\left( \pm 1.78^{\mathrm{ac}}\right)\end{array}$ & $\begin{array}{c}6.27 \\
\left( \pm 0.46^{\mathrm{a}}\right)\end{array}$ & $\begin{array}{c}5.36 \\
\left( \pm 0.01^{\mathrm{fbe}}\right)\end{array}$ & $\begin{array}{c}0.86 \\
\left( \pm 0.01^{\mathrm{a}}\right)\end{array}$ \\
\hline
\end{tabular}

$\mathrm{a}_{\mathrm{w}}$, water activity. ${ }^{-\mathrm{a}}$ Different lower case letters in the same row differ in the Bonferroni test $(\mathrm{P}<0.05)$.

Table 2. Biogenic amine mean contents ( \pm standard deviation; mg•kg-1) in different Italian-type salami brands sold in Niteroi, RJ, Brazil.

\begin{tabular}{|c|c|c|c|c|c|c|c|}
\hline Brands & TYR & PUT & CAD & SPD & HIS & SPE & Total \\
\hline A & $\begin{array}{c}339.17 \\
\left( \pm 0.16^{\mathrm{a}}\right)\end{array}$ & $5.98\left( \pm 0.01^{\mathrm{a}}\right)$ & $37.57\left( \pm 0.07^{\mathrm{a}}\right)$ & $\begin{array}{c}7.08 \\
\left( \pm 0.01^{\mathrm{a}}\right)\end{array}$ & $\begin{array}{c}95.31 \\
\left( \pm 0.04^{\mathrm{a}}\right)\end{array}$ & $\begin{array}{c}8.81 \\
\left( \pm 0.01^{\mathrm{a}}\right)\end{array}$ & 493.93 \\
\hline B & $\begin{array}{c}237.10 \\
\left( \pm 0.11^{\mathrm{a}}\right)\end{array}$ & $234.27\left( \pm 0.04^{b}\right)$ & $9.08\left( \pm 0.01^{\mathrm{a}}\right)$ & $\begin{array}{c}5.84 \\
\left( \pm 0.00^{\mathrm{a}}\right)\end{array}$ & $\begin{array}{c}169.96 \\
\left( \pm 0.04^{\mathrm{a}}\right)\end{array}$ & $\begin{array}{c}2.22 \\
\left( \pm 0.00^{\mathrm{a}}\right)\end{array}$ & 658.47 \\
\hline C & $\begin{array}{c}94.26 \\
\left( \pm 0.01^{\mathrm{a}}\right)\end{array}$ & $109.24\left( \pm 0.08^{\mathrm{ab}}\right)$ & $132.56\left( \pm 0.05^{b}\right)$ & $\begin{array}{c}1.08 \\
\left( \pm 0.00^{\mathrm{a}}\right)\end{array}$ & $\begin{array}{c}24.53 \\
\left( \pm 0.00^{\mathrm{a}}\right)\end{array}$ & $\begin{array}{c}79.36 \\
\left( \pm 0.03^{\mathrm{b}}\right)\end{array}$ & 441.03 \\
\hline D & $\begin{array}{c}190.07 \\
\left( \pm 0.08^{\mathrm{a}}\right)\end{array}$ & $15.06\left( \pm 0.00^{\mathrm{a}}\right)$ & $23.79\left( \pm 0.00^{\mathrm{a}}\right)$ & $\begin{array}{c}2.84 \\
\left( \pm 0.00^{\mathrm{a}}\right)\end{array}$ & $\begin{array}{c}47.79 \\
\left( \pm 0.02^{\mathrm{a}}\right)\end{array}$ & $\begin{array}{c}23.57 \\
\left( \pm 0.01^{\mathrm{a}}\right)\end{array}$ & 303.12 \\
\hline $\mathrm{E}$ & $\begin{array}{c}163.27 \\
\left( \pm 0.07^{\mathrm{a}}\right)\end{array}$ & $41.03\left( \pm 0.00^{\mathrm{a}}\right)$ & $\begin{array}{c}22.40 \\
\left( \pm 0.00^{\mathrm{a}}\right)\end{array}$ & $\begin{array}{c}6.24 \\
\left( \pm 0.00^{\mathrm{a}}\right)\end{array}$ & $\begin{array}{c}127.43 \\
\left( \pm 0.02^{\mathrm{a}}\right)\end{array}$ & $\begin{array}{c}15.94 \\
\left( \pm 0.01^{\mathrm{a}}\right)\end{array}$ & 376.31 \\
\hline $\mathrm{F}$ & $160.68\left( \pm 0.12^{\mathrm{a}}\right)$ & $454.14\left( \pm 0.07^{c}\right)$ & $\begin{array}{c}212.71 \\
\left( \pm 0.02^{b}\right)\end{array}$ & $\begin{array}{c}4.02 \\
\left( \pm 0.01^{\mathrm{a}}\right)\end{array}$ & $\begin{array}{c}78.95 \\
\left( \pm 0.04^{\mathrm{a}}\right)\end{array}$ & $\begin{array}{c}87.09 \\
\left( \pm 0.00^{b}\right)\end{array}$ & 997.59 \\
\hline Mean & 197.43 & 143.29 & 73.02 & 4.52 & 90.66 & 36.17 & 545.09 \\
\hline
\end{tabular}

TYR, tyramine; PUT, putrescine; CAD, cadaverine; SPD, spermidine; HIS, histamine; SPE, spermine. ${ }^{\text {a-c }}$ Different lowercase letters in the same row differ in the Bonferroni test (P<0.05). 
meat products (Suzzi and Gardini, 2003).

The levels of BAs showed fluctuations among the different salami brands assessed. These variations may be due to differences in the quality of raw materials and hygienic conditions during the processing of raw materials, and technological factors such as temperature, $\mathrm{pH}$, redox potential, water activity, $\mathrm{NaCl}$ content, the availability of precursor amino acids, processing time, storage temperature and decarboxylase enzyme of degraded extracellular bacterial contaminants can also determine the formation of BA (Suzzi and Gardini, 2003; Carmo et al, 2010; Stadnik, 2013).

Another factor that contributes to different values between the brands is the lack of uniformity in the weight and diameter of the samples. A relationship between the diameter of the sausage and the concentration of biogenic amines has been demonstrated. It occurs due to the degree of anaerobiosis, degree of proteolysis, redox potential, $\mathrm{pH}$ and $\mathrm{Aw}$, which may be different at the edge in relation to the center. Therefore, the center has a higher microbial activity and may be one of the reasons for increased production during fermentation of certain amines such as tyramine and putrescine (Bover-Cid et al., 1999; Suzzi and Gardini, 2003; Komprda et al., 2009).

The brands A, B, C and F presented higher amine content than D and E. Coincidentally, these four brands declared the use of starter culture on their labels. This result differs from that reported by Jover et al. (1997) who reported that sausages fermented by starter cultures had a smaller production of tyramine, putrescine and cadaverine than natural fermented sausages. This fact might be explained by the competition of the starter cultures with other microbial types (spoilage) present in natural fermentation (Bover-Cid et al., 2000). Although the culture type was not declared on the labels and we do not have information on the type used by each brand, it can be suggested that the starter culture influences amine formation (Parente et al., 2001).

Histamine is the only BA with legal limits (maximum $100 \mathrm{mg} \bullet \mathrm{kg}-1$ ) defined for scombroid fishes (Ladero et al., 2010). In the present study, the B and E brands showed high histamine values 169.96 and $127.43 \mathrm{mg} \bullet \mathrm{kg}^{-1}$ respectively, which exceed this limit. Although fermented foods are indicated as BA source, limits have not been defined in products like salami.

In this study, the brand A showed highest value of tyramine $(339.17 \mathrm{mg} \bullet \mathrm{kg}-1)$ among the analyzed brands. Normal consumption of tyramine is $100-800 \mathrm{mg} \bullet \mathrm{kg}^{-1}$ while levels higher than $1080 \mathrm{mg}^{\circ} \mathrm{kg}^{-1}$ are considered toxic. However, persons under MAOI treatment are more susceptible to tyramine consumption and values of $60 \mathrm{mg} \cdot \mathrm{kg}^{-1}$ in diet could produce a mild crisis, whereas $100-250 \mathrm{mg} \bullet \mathrm{kg}^{-1}$ is asso- ciated to severe headache with intracranial hemorrhage and sequelae (FAO/WHO, 2013).

We found values of tyramine similar to those reported by Papavergou and colleagues (2012), who assessed qualitative and quantitative profile of BAs in 40 samples of salami commercialized in Greece, and obtained concentrations of 197.7, 96.5, 3.6 and $7.0 \mathrm{mg} \bullet \mathrm{kg}-1$ for tyramine, putrescine, cadaverine and histamine respectively. However our values of putrescine and histamine were lower than those found by the same authors. The authors concluded that the level of biogenic amines measured in a notable proportion of fermented sausages might not quite guarantee their safe consumption. High amounts ingested with food and/or presence of some genetic, physiological or acquired dysfunction of the enzymes that participate in the process of degradation of these amines may lead to toxicological reactions (EFSA, 2011).

\section{Conclusions}

The results of our study indicate that the physicochemical control of commercial Italiantype salami is necessary, particularly moisture and protein contents, because only $50 \%$ of the brands analyzed met the requirements of Brazilian law. The fluctuations of the microbiological results suggest an inadequate control of the raw matter quality and of the process hygiene, being necessary a control of other bacterial groups to discard contamination during the process. Despite the brands A, E and $\mathrm{F}$ meet the requirements fixed by the Brazilian legislation for the physical-chemical parameters, the same brands may not guarantee a safe consumption, depending on the amount ingested and/or the presence of some dysfunction in metabolism, due to the high total BA concentrations shown and the highest values of some amines, especially tyramine, putrescine, cadaverine and histamine. Therefore, we recommend that the industry and federal institutions carry out a periodic evaluation and implement specific standards for BAs in salami in the Brazilian code for food and beverages.

\section{References}

Ambrosiadis J, Soultos N, Abrahim A, Bloukas JG, 2004. Physicochemical microbiological and sensory attributes for the characterization of Greek traditional sausages. Meat Sci 66:279-87.

Bover-Cid S, Pulido MI, Carou MCV, 2000. Mixed starter cultures to control biogenic amine production in dry fermented sausa- ges. J Food Protect 63:1556-62.

Bover-Cid S, Schoppen S, Pulido MI, Carou MCV, 1999. Relationship between biogenic amine contents and the size of dry fermented sausages. Meat Sci 5:305-11.

Brazilian Republic, 2000. Instrução normativa $\mathrm{n}^{\circ} 22$, de 31 de julho de 2000. Regulamentos técnicos de identidade e qualidade de copa, de jerked beef, de presunto tipo parma, depresunto cru, de salame, de salaminho, de salame tipo alemão, de salame tipo calabrês, de salame tipo friolano, de salame tipo napolitano, de salame tipo hamburguês, de salame tipo italiano, de salame tipo Milano, de lingüiça colonial e pepperoni. In: Diário Oficial da República Federativa do Brasil, Brasília, 03-08-2000, p. 15.

Brazilian Republic, 2003. Instrução Normativa $\mathrm{n}^{\circ} 62$, de 26 de agosto de 2003. Oficializa os métodos analíticos oficiais para análises microbiológicas para controle de produtos de origem animal e água. In: Diário Oficial da República Federativa do Brasil, Brasília, 26-08-2003, p. 14.

Caccioppoli J, Custódio FB, Vieira SM, Coelho JV, Glória MBA, 2006. Aminas bioativas e características físico-químicas de salames tipo italiano. Arq Bras Med Vet Zoo 58:64857.

Cardozo M, Lima K, Franca T, Lima AL, 2013. Aminas biogênicas: um problema de saúde pública. Rev Vir Quím 5:149-68.

Carmo FBT, Mársico ET, Clemente SC, Carmo RP, Freitas MQ, 2010. Histamine in canned sardines. Ciênc Anim Bras 11:174-80.

Castro LC, Luchese RH, Martins JFP, 2000. Efeito do uso da cepa starter de Penicillium nalgiovense na qualidade de salames. Food Sci Technol 20:40-6.

Demeyer DI, Vandekerckhove P, Moermans R, 1979. Compounds determining $\mathrm{pH}$ in dry sausage. Meat Sci 3:161-7.

EFSA, 2011. Scientific opinion on risk based control of biogenic amine formation in fermented foods. Panel on biological hazards (BIOHAZ). EFSA J 9:1-93.

FAO/WHO, 2013. Public health risks of histamine and other biogenic amines from fish and fishery products. Food and Agriculture Organization, Rome, Italy.

Halász A, Baráth Á, Simon-Sarkadi L, Holzapfel W, 1994. Biogenic amines and their production by microorganisms in food. Trends Food Sci Technol 5:42-9.

Jover TH, Pulido MI, Nogues, MTV, Font AM, Carou MCV, 1997. Effect of starter cultures on biogenic amine formation during fermented sausage production. J Food Prot 60:825-30.

Komprda T, Sládková P, Dohnal V, 2009. Biogenic amine content in dry fermented sausages as influenced by a producer, spice mix, starter culture, sausage diame- 
ter and time of ripening. Meat Sci 83:53442.

Ladero V, Calles-Enriquez M, Fernández M, Alvarez M, 2010. Toxicological effects of dietary biogenic amines. Curr Nutr Food Sci 6:145-56.

Lázaro de la Torre CA, Conte-Junior CA, Cunha FL, Mársico ET, Mano SB, Franco RM, 2013. Validation of an HPLC methodology for the identification and quantification of biogenic amines in chicken meat. Food Anal Method 6:1024-32.

Lima IA, 2009. Elaboração e caracterização de salame de cordeiro santa inês. Degree Diss., Universidade estadual do sudoeste da Bahia, Brazil.

Lücke FK, 2000. Utilization of microbes to process and preserve meat. Meat Sci 56:10515.

Ordóñez JA, Hierro EM, Bruna JM, Hoz L, 1999. Changes in the components of dry-fermented sausages during ripening. Crit Rev Food Sci Nutr 39:329-67.

Papavergou EJ, Savvaidis IN, Ambrosiadis IA, 2012. Levels of biogenic amines in retail market fermented meat products. Food
Chem 135:2750-5.

Parente E, Martuscelli M, Gardini F, Grieco S, Crudele MA, Suzzi G, 2001. Evolution of microbial populations and biogenic amine production in dry sausages produced in Southern Italy. J Appl Microbiol 90:882-91.

Peltier M, 2013. Fãs da linguiça e ranking doméstico. Associação brasileira da indústria produtora e exportadora de carne suína. Available from: http://www.abipecs.org.br/news/206/135/Fa s-da-Linguica-e-Ranking-Domestico.html

Rodriguez MBR, Carneiro CS, Feijó MBS, Conte Júnior CA, Mano SB, 2014. Bioactive amines: aspects of quality and safety in food. Food Nutr Sci 5:138-46.

Ross RP, Morgan S, Hill C, 2002. Preservation and fermentation: past, present and future. Int J Food Microbiol 79:3-16.

Scheid GA, 2001. Avaliação físico-química e sensorial de salame tipo italiano contendo diferentes concentrações de cravo-daíndia (Eugenia caryophyllus). Degree Diss., Universidade Federal de Viçosa, Brazil.

Silva VL, Lázaro CA, Teixeira E, Mano SB,
Conte Junior CA, 2013. Aminas biogênicas como indicadores de qualidade de salames e produtos cárneos fermentados. Enciclopédia Biosfera 9:69-84.

Stadnik J, 2013. Biogenic amines in dry cured meat products. Zywn-Nauk Tech J 88:5-15.

Suzzi G, Gardini F, 2003. Biogenic amines in dry fermented sausages: a review. Int $\mathbf{J}$ Food Microbiol 88:41-54.

Terra ABM, Fries LL, Terra NN, 2004. Particularidades na fabricação de salame. Livraria Varela, São Paulo, SP, Brazil.

Tussi EK, Locatelli PP, Trindade AA, 2008. Avaliação da qualidade físico-química e microbiológica do salame colonial comercializado em São Jorge D'oeste-PR. Available from: http://revistas.utfpr.edu.br /pb/index. php/SysScy/article/view/324

Vinci G, Antonelli ML, 2002. Biogenic amines: quality index of freshness in red and white meat. Food Control 13:519-24.

Zenebon 0, Pascuet NS, Tigela P, 2008. Métodos físico-químicos para análise de alimentos. 4 th ed. Instituto Adolfo Lutz, São Paulo, SP, Brazil. 